\title{
The Pitfalls in Entrepreneurship and Small Business Research: A Holistic View
}

\author{
Mohd Sobri Minai ${ }^{1}$, Md Mohan $\operatorname{Uddin}^{1} \&$ Yusnidah Ibrahim ${ }^{1}$ \\ ${ }^{1}$ College of Business, Universiti Utara Malaysia, Sintok, Kedah, Malaysia \\ Correspondence: Mohd Sobri Minai, School of Business Management, College of Business, Universiti Utara \\ Malaysia, Sintok 06010, Kedah, Malaysia. Tel: 6-012-475-6428. E-mail: msminai@uum.edu.my
}

Received: November 10, 2013

doi:10.5539/ass.v10n6p122
Accepted: December 31, 2013 Online Published: February 26, 2014

URL: http://dx.doi.org/10.5539/ass.v10n6p122

\begin{abstract}
The academic and practical interest in the field of small business and entrepreneurship has recently gained considerable attention. However, an important area of concern within this field has been to find appropriate and suitable research approach or technique that could assist the researchers to produce positive research outcomes. Many researches in this field have been conducted without paying attention to some of their unique characteristics. Therefore, this study identifies and documents various pitfalls associated with these types of researches. It also offers the guidelines and important considerations for researchers in this area with the intention of reducing future weaknesses.
\end{abstract}

Keywords: research methodology, small business, entrepreneurship research

\section{Introduction}

Management research as a discipline has existed for hundreds of years, especially in the area of accounting and marketing and has further become more popular in the recent times. It is not surprising that ten years ago Zikmund (2003) has pointed that business research becomes increasingly global and suggested that it would continue to be more especially in this current dispensation of the 21 st century. Contemporary researches (Coviello et al., 2011), also emphasis on the increasing global integration of entrepreneurial activity and exhibit significant impact on mainstream management literature. Thus, we have realized that many researches have been conducted in this area with the aim to increase business and management knowledge and practical contributions to the business firms or organizations around the globe. Therefore, the importance of business research in management cannot be undermined. Business research is management tool that assists companies, firms and organizations to reduce uncertainty. It also provides managers and business owners' vital information about their current business situations, environmental conditions and the general information about their business (Zikmund \& Babin, 2009).

It is important to note here that small business and entrepreneurship have been grouped together in the management discipline as one of the subsets of management discipline. However, the small businesses and the small entrepreneurs have unique characteristics that make them different from others. Thus, many scholars have called for the need to consider these differences when examining them.

Focusing particularly on small business and entrepreneurship research, although management research as a discipline has existed for hundreds of years, research in these areas has only recently drawn considerable attention among academic researchers. Mitchell (2011) has highlighted that the number of entrepreneurship related articles in academic journals has grown largely at an increasing rate. The progress of small business and entrepreneurship research is significant enough to get the recognition of an important scientific domain (Mullen et al., 2009).

The field of small business and entrepreneurship is yet to nurture its respected and well developed voice (Minai \& Lucky, 2011). Minai (2001) has long argued that small firms and small entrepreneurial firms are unique with different unique individuals running the firms. Thus, he called for a change in the current business research approach to a more unique approach that would give attention to the uniqueness of the small and entrepreneurial firms and how to address this uniqueness whilst conducting research on them. He further argued that the formal approach has not been able to capture the aspects of small and entrepreneurial firms significantly since the 
uniqueness of these small firms have not been taken into consideration.

Accordingly, Peters and Howard (2001) have long argued that researchers and authors in the management field are yet to agree on a common research methodology that best suit small business and entrepreneurship field. Particularly for the academic field of entrepreneurship research, Aldrich (2012) describes that the choice of research topic and method are affected by American hegemony. In line with that, Mullen et al. (2009) calls for the development of strong methodological foundation for the paradigmatic growth and maturation of the small and entrepreneurship research after critical analysis of methodologies in small business and entrepreneurship research during the last decade. Thus, the argument is still debatable.

Minai and Lucky (2012) essentially argued that the field of management needs to be developed over a period, particularly referring to the small businesses. Moreover, regardless of the stage of development, the need for periodic evaluation of theoretical and methodological progress is recognized for every discipline. Particularly, the small business and entrepreneurship discipline could not be fully rich with its own core knowledge as its theoretical development is still dependent on other mainstream literature (Landstrom et al., 2012). However, only a few or no current studies have examined the methodological issues with regard to the small business and entrepreneurship field. Therefore, the aim of this study is to review the methodological issues for an empirical examination of small and entrepreneurial firms. However, engaging in a philosophical debate about the merits or otherwise of particular research paradigms is not within the scope of this study. Thus, this present topic, the pitfalls in small business and entrepreneurship research-a holistic view, becomes very crucial and imperative.

\section{Pitfalls of Entrepreneurship and Small Business Research Method}

The norm of practice in management research which includes research in entrepreneurship has always been the utilization of quantitative methodology (Creswell, 2012; Hair et al., 2009). The debates among academics have continued on the strengths and weaknesses of both qualitative and quantitative research methodologies focusing on philosophical levels (Minai, 2001). It is argued here that the choice of quantitative method is not always the right choice due to the unique characteristics of small businesses and small size of entrepreneurship. There are a number of considerations to be observed whilst taking research work on these businesses.

It is the intention of this study not to discuss on the research paradigm and philosophy or which methodology is better than the other because that could lead to digging deep into their philosophical viewpoints. The objective is rather to pinpoint some of the pitfalls and shortcomings in the management research methodology with particular emphasis on small business and small entrepreneurial firms.

It has been argued that researchers should always give attention to the research tools, however, many studies have not heeded to this call (Minai, 2001). Supporting this argument, researchers should give serious attention to any research process which includes human interpretation to ensure that the findings are given more value and also seen as being productive (Creswell, 2012). This is true most especially in the field of entrepreneurship development which always involves human interpretation. Furthermore, to adequately utilize an appropriate and suitable research approach on small firms as well as entrepreneurial businesses, one needs to understand some of the major underlying philosophy regarding their operations, characteristics and the nature of these entrepreneurial businesses and small businesses in line with the research methodology and the problem associated with such research approaches. Therefore, further arguments on these are organized and discussed in the following sections.

\subsection{The Fragmented Nature of Entrepreneurship Research}

Entrepreneurship research has been noted as highly fragmented by many scholars (e.g., Aldrich, 2012; Carlsson et al., 2012), which is an obstacle to the field's scholarly development as well as to its legitimization among the management discipline. Carlsson et al. (2012) argued that researcher in this field should be aware of the fragmented nature of current research involves highly differentiated and divergent research techniques and approaches with little or no similarity and common background with respect to the shared knowledge and mode of operation. Thus, the fragmented nature which the study derives from the narrow and specific matters, do not incorporate other works which relate to them. Again, the heterogeneity of the entrepreneurial firms should also be taken into consideration. It has been noted that the entrepreneurial firms are usually flexible and informal. Thus, they could be said to be much dependent on the entrepreneurs' characteristics.

It is also argued that smaller firms can be likened to the individual human being or set of individual human beings which possess different characteristics and unique in the way they do things or in operations. Therefore, research in entrepreneurship should take care of these, if qualified and acceptable results are to be produced. All in all, one should observe every entrepreneurial small firm is distinct from another and also distinct from the 
larger firms in many ways. It is important to point out that small firms should be considered different from the larger firms. The application of the larger firm's research approach or paradigm into entrepreneurial small firms could give a misunderstanding and produce incorrect results.

\subsection{The Ad-hoc Manner of Model Development}

Another point is that the research in the field of entrepreneurship could be said to be ad-hoc and fragmented. The differentiation, fragmentation and possible loss of theoretical eclecticism of this area are stressed by Aldrich (2012). Most of the time the research methodology spring up as a result of the purpose of the research to serve the need and after that there is no continuing relationship among them, making it very difficult for one to actually apply the research methodology of one entrepreneurial firm to another entrepreneurial firm.

Supporting this, is the fact that the research in this field lack continuity that is there is no continuity with respect to research methodology of the entrepreneurial firms while there seem to be a sort of continuity among small businesses. Its methodology is not always applicable to another entrepreneurial firm research. Thus, every research on entrepreneurial firm end up after the research has been done or carried out.

\subsection{Lack of Actual Management Experience}

Some of the academic researchers lack the actual experience to conduct management research, meaning that their knowledge are always based on the journal, textbooks and other writings rather than being based on the experience of the real world of entrepreneurial firms, entrepreneurs and small businesses.

\subsection{The Traditional Science Researchers}

It is observed that too many researchers are trained in traditional science. Because of the traditional scientific nature of some researchers, they become too explicit with objectivity and empirical evidence. Therefore, this has made many researchers in management particularly in small business and entrepreneurship to rely too much on the traditional science rather than their own intuition and judgments, using science to explain their area of interest. It is therefore argued that this could bring about prejudice against historical analysis and in-depth descriptive case analysis.

\subsection{The Use of Borrowed Theories, Models and Approaches}

It is argued that the field of entrepreneurship and small business lack any theory-base and Carlsson et al. (2012) mention that a very few theoretical article attempts to develop a unique knowledge on entrepreneurship and small business, as a result, this discipline lacks distinctive boundary and consistent theories. Hence, it is not surprising that entrepreneurship researchers borrowed and adapted popular theories from other disciplines to explain diverse phenomena of this discipline (Zahra, 2007). According to Landstrom et al. (2012), during the last decade we could see several other new fields to develop their own concepts and theories, entrepreneurship is still dependent on imported old theoretical frameworks of economics and mainstream management literature. However, the borrowing and use of methods and theories from other disciplines to explain entrepreneurial firm might not produce a good and solid foundation for this discipline. So, there will be difficulties in developing the theoretical framework which is based on reliable theories to foothold the study in this area.

Minai (2001) suggest the use of partial frameworks to support the research work in this area. Therefore, self-produce a relevant research approach is needed to circumvent or reduce or minimize the research weaknesses inherent in the area of small business and entrepreneurship development. Zahra (2007) suggests that researchers in this field should be able to delineate the boundaries and new aspects of the entrepreneurship context and should question the widely held assumptions of the borrowed theories.

\subsection{Conceptual Convergence}

Conceptual convergence refers to the characterization of an intellectual field in an increasing manner by a set of theories, models, methods and/or measures that directs ongoing research in the field (Gregoire et al., 2006). The starting of conceptual convergence follows some exemplary research by earlier researchers, which can attract other researchers. Essentially, the scientific progress of a discipline is reflected in the degree of conceptual convergence. Analysing last 25 years research on entrepreneurship, Gregoire et al. (2006) reveals that the field of entrepreneurship exhibits a low level of conceptual convergence. The nature of convergence is not stable; rather it shows alternative convergence and divergence of scholarly discussions over time.

\subsection{Consensus about the Phenomenon of Entrepreneurship}

The lack of consensus about the definition of entrepreneurship is prevalent at least for two reasons: first, scholars do not follow the same definition as the multidimensional nature of entrepreneurship discipline result them to define it based on the focus of the research undertaken; second, absence of universal indicator results the 
definition to vary over time and across countries. Among the many ways used to relate the entrepreneurship phenomena include the behavior of both individual entrepreneur and that of the firm created and run by the individual (Davidsson, 2005). Therefore, scholarly development should be based on distinctive definition entrepreneurial phenomena separately.

\subsection{Reliability and Validity Issues}

Like any other discipline, reliability of the measurements is critical for the advancement of entrepreneurship research. Unreliable measures often result conflicting findings across comparable studies because of measurement errors (Boyd et al., 2005), which may hinder the smooth advancement of knowledge. Crook et al. (2010) find that though the results are satisfactory regarding internal reliability, very few of the entrepreneurship studies reported regarding inter-respondent reliability. Their results also show that number of studies depending solely on secondary data is increasing compared to those depending on primary data and on triangulation of both In addition, about $90 \%$ of the studies are single country analyses and $55 \%$ of the studies are conducted in the US context. Therefore, in order to improve the external validity of the findings in entrepreneurship discipline, researchers may need to consider using the triangulation method as well as go for more cross-country studies.

\subsection{Multiplicity of the Context of Entrepreneurship}

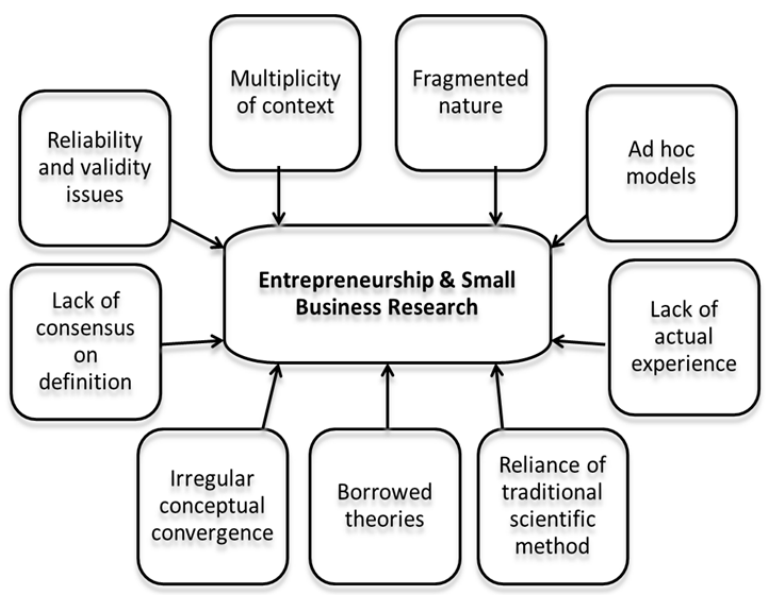

Figure 1. The holistic view of the pitfalls in entrepreneurship and small business research

Context can be defined as situational opportunities and constraints effecting behaviour (Johns, 2006). It is a known fact that context has three dimensions: 'who', 'where' and 'when'. From the entrepreneurship research perspective, 'who' reflects the impact of the other two dimensions, 'where' and 'when' that define the context of entrepreneurship (Welter, 2011). The context of entrepreneurship is multifaceted, it affects the aspects of entrepreneurship through the different levels such as either through political situation or through family size, even context can have cross level effect (Johns, 2006), moreover it can affect directly or indirectly (Whetten, 2009). On top of that, entrepreneurial activities also influence the change of context (Boettke \& Coyne, 2009). Given this complex nature of contextual influence on entrepreneurship, entrepreneurship research must adhere to the challenging task of proper contextualization in different stages of the study. However, most of the entrepreneurship research fails to consider this variability of context and consider the discrete context which is very specific (Welter, 2011). Therefore, in line with Welter (2011), research questions and designs should account for situational and temporal boundaries of the entrepreneurship, researchers should recognize two way relationships between entrepreneurship and context and utilize qualitative and/or mixed method research in order to capture the multifaceted contextual effects.

\section{Summary and Conclusion}

The aim of this study is to review the methodological options for an empirical examination of small business and entrepreneurship research. Selection of an appropriate research methodology is no doubt fundamental to the success of any management research particularly small business and entrepreneurial research. This study argues that the most appropriate research methodology for both small and entrepreneurial firms is the methodology that considered the uniqueness of the small and entrepreneurial firms. Therefore, there is a need for the small business and entrepreneurship researchers to develop a research methodology that could assist them to conduct research that would address the peculiar and unique nature of the small and entrepreneurial firms bearing in mind 
their individualistic characteristics. Therefore, the research methodology on small and entrepreneurial firms should be different from the methodologies of the other firms. It has to be 'best-fitted' to the problems and it is essential to adopt a research methodology that would justify the study based on the present environment and situation. More specifically, this study identifies and calls for improving research methodology on following issues (as shown in Figure 1): fragmented nature, ad hoc manner of model development, lack of actual experience of researcher in small and entrepreneurial business, lack of focus on intuition and judgment in the research process, overuse of borrowed theories, unstable nature of conceptual convergence, lack of consensus about the definition of entrepreneurship, need for improving reliability and external validity and multiplicity of the context of entrepreneurship. It is hoped that this study would assist researchers in this area to select an appropriate research methodology, by so doing; researchers in this area would progress beyond the often-limited methodological perspective of small and entrepreneurial firms' researches. With regard to this, it is hoped that this present paper will provide a springboard that will provide an impetus for empirical research in this area.

\section{References}

Aldrich, H. E. (2012). The emergence of entrepreneurship as an academic field: A personal essay on institutional entrepreneurship. Res. Policy, 41, 1240-1248. http://dx.doi.org/10.1016/j.respol.2012.03.013

Boettke, P., \& Coyne, C. (2009). Context matters: Institutions and entrepreneurship. Foundations Trends Entrepreneurship, $\quad 5, \quad 135-209 . \quad$ Retrieved from http://www.amazon.com/Context-Matters-Institutions-Entrepreneurship-Foundations/dp/1601982062; http://dx.doi.org/10.1561/0300000018

Boyd, B. K., Gove, S., \& Hitt, M. A. (2005). Consequences of measurement problems in strategic management research: The case of Ahimud and Lev. Strategic Manage. J., 36, 367-375. http://dx.doi.org/10.1002/smj.445

Bull, I., \& Thomas, H. (1993). Editors' note: A perspective on theory building in Entrepreneurship. J. Bus. Ventur., 8, 181-182. http://dx.doi.org/10.1016/0883-9026(93)90025-Z

Carlsson, B., Braunerhjelm, P., Mckelvey, M., Olofsson, C., Persson, L., \& Ylinenpää, H. (2012). The evolving domain of entrepreneurship research. CESIS Electronic Working Paper Series, Paper no 284, International Joseph A. Schumpeter Society, July, Brisbane, Australia. Retrieved from http://www.e-award.org/Wfiles/Wp948.pdf

Coviello, N. E., McDougall, P. P., \& Oviatt, B. M. (2011). The emergence, advance and future of international entrepreneurship research-An introduction to the special forum. J. Bus. Ventur., 26, 625-631. Retrieved from $\mathrm{http} / / / \mathrm{www}$. deepdyve.com/lp/elsevier/the-emergence-advance-and-future-of-international-entrepreneurship$51 \mathrm{~m} 1 \mathrm{fnaNjP}$; http://dx.doi.org/10.1016/j.jbusvent.2011.07.002

Creswell, J. W. (2012). Qualitative Inquiry and Research Design: Choosing among Five Approaches (3rd ed.). SAGE Publications.

Crook, T. R., Shook, C. L., Morris, M. L., \& Madden, T. M. (2010). Are we there yet? An assessment of research design and construct measurement practices in entrepreneurship research. Organ. Res. Methods, 13, 192-206. http://dx.doi.org/10.1177/1094428109334368

Davidsson, P. (2005). Researching Entrepreneurship (1st ed., p. 218). Springer, Boston.

Gregoire, D. A., Noel, M. X., Dery, R., \& Bechard, J. P. (2006). Is there conceptual convergence in entrepreneurship research? A co-citation analysis of frontiers of entrepreneurship research. Entrepreneurship Theory Practice, 30, 333-373. http://dx.doi.org/10.1111/j.1540-6520.2006.00124.x

Hair, J. F., Black, W. C., Babin, B. J., \& Anderson, R. E. (2009). Multivariate Data Analysis (7th ed.). Prentice Hall, NJ.

Johns, G. (2006). The essential impact of context on organizational behaviour. Acad. Manage. Rev., 31, 386-408. http://dx.doi.org/10.5465/AMR.2006.20208687

Landstrom, H., Harirchi, G., \& Astrom, F. (2012). Entrepreneurship: Exploring the knowledge base. Res. Policy, 41, 1154-1181. http://dx.doi.org/10.1016/j.respol.2012.03.009

Minai, M. S. (2001). An examination of the potential for enhancing Malaysian small-medium size business activity in export markets within the furniture and halal food sub-sectors. Unpublished dissertation in partial fulfillment of the requirements for the degree of doctor of philosophy. De Montfort University. UK.

Minai, M. S., \& Lucky, I. O. E. (2011). The moderating effect of location on small firm performance: Empirical 
evidence. Int. J. Bus. Manag., 6, 178-192. Retrieved from http://www.ccsenet.org/journal/index.php/ijbm/article/ view/12510

Minai, M. S., \& Lucky, I. O. E. (2012). Re-investigating the effect of individual determinant, external factor and firm firm characteristics on small firm performance during economic downturn. African Journal of Business Management, 5, 229-237.

Mitchell, R. K. (2011). Increasing returns and the domain of entrepreneurship research. Entrepreneurship Theory Practice, 35, 615-629. http://dx.doi.org/10.1111/j.1540-6520.2011.00473.x

Mullen, M. R., Budeva, D. G., \& Doney, P. M. (2009). Research methods in the leading small business-entrepreneurship journals: A critical review with recommendations for future research. J. Small Bus. Manage., 47, 287-307. http://dx.doi.org/10.1111/j.1540-627X.2009.00272.x

Peters, J., \& Howard, K. (2001). Looking for good research in management-a publishers' case study. Manage. Decision, 39, 594-698. http://dx.doi.org/10.1108/EUM0000000005804

Welter, F. (2011). Contextualizing entrepreneurship-conceptual challenges and ways forward. Entrepreneurship Theory Practice, 35, 165-184. http://dx.doi.org/10.1111/j.1540-6520.2010.00427.x

Whetten, D. A. (2009). An examination of the interface between context and theory applied to the study of Chinese organizations. Manage. Organ. Rev., 5, 29-55. http://dx.doi.org/10.1111/j.1740-8784.2008.00132.x

Zahra, S. A. (2007). Contextualizing theory building in entrepreneurship research. J. Bus. Ventur, 22, 443-452. http://dx.doi.org/10.1016/j.jbusvent.2006.04.007

Zikmund, W. G. (2003). Business Research Method (2nd ed., p. 397). Excel Books India, New Delhi Excel Books.

Zikmund, W. G., \& Babin, B. J. (2009). Essentials of Marketing Research (4th ed.). Cengage Learning.

\section{Copyrights}

Copyright for this article is retained by the author(s), with first publication rights granted to the journal.

This is an open-access article distributed under the terms and conditions of the Creative Commons Attribution license (http://creativecommons.org/licenses/by/3.0/). 